\title{
Textual Community: Reconceptualizing of Manggarai Inheritance Customary Law for Gender Justice
}

\author{
Adrianus Marselus Nggoro \\ \{adrianusnggoro@gmail.com\} \\ Universitas Katolik Indonesia Santu Paulus Ruteng, Indonesia ${ }^{123}$
}

\begin{abstract}
Manggarai inheritance customary law has a philosophy "ata pe'ang ko ata one". This philosophy has an impact on the dichotomy of boy's outsiders and girls as insiders. Therefore, there is an assumption that the textual community positions boys as heirs (superior class) and women as non-heirs (inferior class). This assumption is investigated further. But the results showed that: (1) A small part of the textual community divides inheritance to daughters, in the form of private land inheritance, while communal land (lingko) is only inherited by sons as guardians of the clan. 2) The textual society is conditionally open to the distribution of inheritance to daughters, because it is influenced by factors of education, employment, economy. (3) The law system of the Manggarai community based in the future is inheritance customary law with an open patrilineal customary law system and gender justice
\end{abstract}

Keywords: reconceptualizing; inheritance customary law; open patrilineal; textual society; gender justice

\section{Introduction}

Previous research has revealed barriers to the practice of Manggarai inheritance customary law because it is influenced by indigenous peoples (textual communities) who are still strongly tied to the Manggarai cultural philosophy "ata pe'ang ko ata one" (outsiders and insiders) [25] So, this is an indication of the dominance of the patrilineal inheritance customary law practice. And also, that matter there is a Manggarai habit, namely kawe wau (patrilineal) [36]. And Tua Teno divides the inheritance of customary law only to boys.[21], [17] The concept of boys and girls is closely related to gender differences [17], [18],[19]. Therefore [28]. based on the results of research to educated community informants and employees, showing the face of the reformer community (contextual society). Contextual societies are families that practice law on the autonomy of parents as heirs to their children. The research findings reveal that the legal practice developed by contextual society is a gender-just legal practice. Parents when beating inheritance to their children, do not have to consult with customary leaders, because people have the right to inherit to their children.

Based on this research, this research is a follow-up study on criticism of the textual community (customary stakeholders) as an assumption that causes obstacles to the application of laws that are pro gender justice [28]. To answer this criticism whether it is true that the textual community is an obstacle to gender-just legal practices, the focus of this research is to explore the perspective of the textual community on the practice of patrilineal inheritance law in Manggarai. The problems of this research are as follows (1) How does the phenomenon of 
legal practice built by the textual community through the distribution of patrilineal inheritance position girls as an inferior class? (2) What are the factors that underlie the textual society sharing open patrilineal inheritance? (3) How is the aspect of gender justice towards the open patrilineal inheritance customary law system as a contribution of thought to the practice of sharing Manggarai customary heritage in the future?

\section{Method}

The main text should be written using Times New Roman, 10pt, fully justified. Italics can be used for emphasis and bold typeset should be avoided. Qualitative research methods, with the approach of Guba Lincoln's constructivism paradigm, and through hermeneutic analysis, symbolic interactionism, dialectics, and phenomenology. Data collection was carried out through observation, interviews and documentation study. Data source, research data source: informant of Gendang Toka customary stakeholders, East Manggarai Regency, Gendang Ra'ong customary stakeholders, Manggarai Regency, and Gendang Namo customary stakeholders, West Manggarai Regency. Data mining techniques: (1) collect data, (2) reduce data, (3) process data (4) conclude data.

\section{Result and Discussion}

\subsection{Result of Data}

Based on the results of data mining in textual communities in three drums (Drum Raong, Drum Toka, and Drum Namo) in Manggarai Raya, it was found textual community responses (indigenous stakeholders) concerning the practice of heritage division in Manggarai culture today. It is seen in the following table:

Table 1. Indigenous Stakeholders Response

\begin{tabular}{|c|c|c|c|c|}
\hline Inheritance & Way of Inheriting & KM-GR & KMT-GT & KMB-GN \\
\hline \multirow[t]{5}{*}{ Lingko } & Widang & Men & Men & Men \\
\hline & Wida & - & - & \\
\hline & Testate of Lingko & $\begin{array}{l}\text { customary } \\
\text { leaders }\end{array}$ & $\begin{array}{l}\text { customary } \\
\text { leaders }\end{array}$ & $\begin{array}{l}\text { customary } \\
\text { leaders }\end{array}$ \\
\hline & heir & Men & Men & Men \\
\hline & $\begin{array}{l}\text { Reason Inheriting to } \\
\text { boys }\end{array}$ & $\begin{array}{l}\text { Heir, } \\
\text { Guardian of } \\
\text { the clan }\end{array}$ & $\begin{array}{l}\text { Heir, } \\
\text { Guardian of } \\
\text { the clan }\end{array}$ & $\begin{array}{l}\text { Heir, } \\
\text { Guardian of the } \\
\text { clan }\end{array}$ \\
\hline \multirow{6}{*}{$\begin{array}{l}\text { Uma Tingkul } \\
\text { (tana weli) }\end{array}$} & Widang & Men & Men & Men \\
\hline & Wida & Women & Women & Women \\
\hline & Testator & Parents & Parents & Parents \\
\hline & heir & - Men & -Men & -Men \\
\hline & & -women & -women & -women \\
\hline & $\begin{array}{l}\text { Reason Inheriting to } \\
\text { women }\end{array}$ & $\begin{array}{l}\text { - love children } \\
\text { - sufficient } \\
\text { land supply, } \\
\text { - no sons (no } \\
\text { men) }\end{array}$ & $\begin{array}{l}\text { - love children } \\
\text { - sufficient } \\
\text { land supply, } \\
\text { - no sons (no } \\
\text { men) }\end{array}$ & $\begin{array}{l}\text { - love children } \\
\text { - sufficient land } \\
\text { supply, } \\
\text { - no sons (no } \\
\text { men) }\end{array}$ \\
\hline
\end{tabular}


home, heirloom

Widang

Wida

Testator

Heir

Reason Inheriting to

boys
Men

Parents

Men

Heir,

Guardian of

the clan
Men

Parents

Men

Heir,

Guardian of

the clan
Men

Parents

Men

Heir,

Guardian of the clan

Description of several terms / abbreviations: KM-GR = Manggarai Regency of Gendang Ra'ong; KMT-GT = East Manggarai Regency of Gendang Toka; KMB-GN = West Manggarai Regency of Gendang Namo. Definition of the word: Lingko = communal land; Widang = inheritance, wida = customary grants; uma tingku/tana weli = private farms, purchased land .

\subsection{Open Patrilineal}

Based on research data on rights as heirs, customary stakeholders recognize that the rights of private land heirs (uma tingkul, uma weli) are parents. However, those who have the right to inherit customary land (Lingko) are the customary holders.[21]. Thus, the rights of customary holders as heirs do not show "domination of rights", because customary stakeholders have evolved the idea that the determination of private inheritance rights is the parents. This indicates that the dominance of customary law as heir, does not only depend on the customary holders (wau), but also the parents themselves as the heirs. This is relevant to Menski's view that there is no legal domination, but law as a law (legal pluralism that moves across national borders).

In connection with the centralized domination of law, Griffiths views this as weak legal pluralism. Weak legal pluralism is another form of legal centralism, because even though in reality state law recognizes the existence of other legal systems, state law is still seen as superior (strong), and meanwhile the state law recognizes the existence of other legal systems. other legal systems are inferior in the hierarchy of the state legal system.[24], [25]. Regarding this singular role of law, Menski criticized that there was no longer any understanding of legal domination. The impact of legal domination causes centralized legal control. State law is no longer understood as dominating law (legal centralism), but legal pluralism is the central point of state law, community law and religious law, ethics, so that it can show justice and balance.[25].

However, the other side of the legal practice that is built by the textual society grows evolutionarily.[15]. And it is evident that some customary stakeholders provide fundamental reasons for conditional acceptance of legal innovations built by contextual communities through expressions of moral independence [15]. Because the right to inherit is the right of the parents, especially the right to share private assets, while the communal property (Lingko) is the right of the customary pemamgku (wa'u). The evolution of that change [23]; freely [35] contextual, and innovative (Sutrisno, et al, 2013), driven by the integrity of the role of agents of the democratic customary version of stakeholders.

Change comes from man himself. These changes occur in the past, present and future time dimensions [23],[13]; then Peursen categorizes changes into cultural stages: the mythic stage, the ontological stage, the functional stage [29], [39], becoming a new habitus (Bourdeau) as a living law has become a new inspiration, to show the elements of responsibility and legal obligations of parents (fathers). This shows that law is born based on habit, the will of society and is full of freedom. In living law practice [12], [41]. 
Thus, ethical values, norms, religion (grunornm), openness to justice, evolutionarily grows in the awareness of the textual community (customary stakeholders), namely legitimizing or dividing inheritance to daughters in the form of inheritance with private dimensions from parents, such as land purchased by parents [8], . Whereas land with a public dimension, namely lingko (communal land / clan land) is only given to boys, because Lingko is a symbol of the glue of the patrilineal clan unity (wa'u). For this reason, Uma Lingko, which is only inherited by boys, is the successor of the father's clan.

Customary holders (textual communities) give freedom to parents as heirs of private rights and provide conditional freedom to share inheritance to girls, relevant to Hans Kalsen's idea of dynamic norms born through the act of the will of individuals who are authorized to form norms, namely delegation a higher authority to a lower autocracy. Customary leaders give full authority to parents (contextual society) to innovate to share inheritance to girls without delegation of customary stakeholders. Customary holders understand the value of changing legal practices built by contextual communities towards gender-equitable inheritance customary law. Textual society appreciates the value of justice as a living law without any turmoil, but gradually (evolutionary) towards an open patrilineal customary law with gender justice.

\subsection{Evolution of Law towards Gender Justice}

In the old paradigm, fully adopting the ata one ko ata pe'ang philosophy, that women are not heirs. The practice of customary law of inheritance in Manggarai which is tied to the philosophy or one ko ata war which dichotomizes the status of boys as heirs (insiders) and women who are not heirs (outsiders), is a legal practice that is seen as not fulfilling the expectations of justice. gender. Women can only get parental assets in the form of wida (identical to a grant), as regulated in Article 1666 of the Code of Civil Law. The position of girls is seen by outsiders. The effect of Manggarai's patrilineal culture is that women who are married then live permanently and die in their husband's clan [38], [2].

However, this research theme reveals the evolution of the thought of customary stakeholders who are pro and contra towards the evolution of law leading to gender justice as established by contextual society, namely dividing inheritance to daughters. As for the reasons for distributing inheritance to daughters, because of parental affection, treating children equally, also if the family does not have sons. This diversity of ways of thinking is a dimensional stage of changing the thinking of customary stakeholders towards the dynamic evolution of laws that leads to the fulfillment of gender justice.

Gender justice is a global issue. Positioning women as equals in relation to each other [1].;[16] That is, as mandated by Law Number 7 of 1984 Article 1 concerning the elimination of discrimination against women (CEDAW Convention), Law Number 39 of 1999 Article 3 paragraph (1), Article 17, Article 36 paragraph 1, Article 48. This, in Presidential Instruction Number 9 of 2000, Law Number 1 of 1974 concerning Marriage, Article 31 paragraphs (1), (2), (3). This in Article 28A-28J of the 1945 Constitution regulates human rights, specifically in the relationship between the natural rights of parents and children. This hope is certainly not radical, but through dynamic legal changes.

Regarding the dynamic law,[30], [20], it is always in the process of being (law as a process, law in the making), just and prosperous. Law was created for man, that is, as a human being, human happiness,[4] welfare, and glory. Awareness of the objectives and basic values of law, namely justice (philosophical values), certainty (juridical values), usefulness (sociological values) and legal objectives: creating justice, stability in life and human welfare.[30], [35], 13] The world of law is famous for the issue of mengeles law (the law 
moves across borders and ages). In line with laws that move across national borders and across ages, it shows that law is not static, but dynamic and always leads to a lofty goal for justice and peace for mankind. The value of justice is increasingly active in the realm of law and human and human rights values at this time, through the issue of legal globalization and modern legal glocalization which demands responsiveness to changes on a global, national and local (regional) scale [3].

\section{Conclusion}

The response of the textual community (customary stakeholders) to the innovation of inheritance customary law built by the contextual community is to accept on the condition that the property given to girls is an inheritance with a private dimension from the parents, while land with a public dimension (Lingko) is only given to children. men, as the successor of the clan. In essence, changes in Manggarai inheritance law are influenced by social and cultural changes. The pluralist social interaction of society and culture between textual and contextual communities has an impact on changes in inheritance customary law that are gradual / gradual in the dimensions of the past, the present to a future that favors the values of justice, gender equality and human rights.

\section{Acknowledgements}

Thanks to the Chancellor Indonesian Catholic University of Santo Paulus Ruteng. and the ICEHA 2021 organized committee of international conferences. and will publish this article.

\section{References}

[1] Baldez, L.: The UN Convention to Eliminate All Forms of Discrimination Against Women (CEDAW): A new way to measure women's interests, cambridge.org, Politics \& Gender 7(3), pp. 419-423 (2011).

[2] Bedner, A. W. J. U. L.,; (2012). "Kajian Sosio-Legal". Universitas Indonesia, Jakarta (2012)."

[3] Benda-Beckmann F, K. Benda-Beckmann and Anne Griffiths (2005), Introduction dalam BendaBeckmann F, K. Benda-Beckmann and Anne Griffiths Mobile People Mobile Law. Expanding Legal Relations in a Contraacting World. USA: Ashgate,

[4] Busro, A.: Pendidikan Tinggi Hukum di Masa Depan Penegakan Hukum di Indonesia (Pengantar: FX.Adji Samekto), Yogyakarta: Thafa Media, hlm.x.(2014)

[5] Erb M.: Conceptualising Culture in a Global Age: Playing Caci in Manggarai. Presented as a Seminar in the Southeast Asian Studies Program. Department of Sociology, National University of Singapore. (2000)

[6] Frederick, B.: Gender turnover and roll call voting in the US Senate, Journal of Women, Politics \& Policy 32(3), Taylor \& Francis, pp. 193-210 (2011).

[7] Friedman, L.M.: Sistem Hukum: Perspektif Ilmu Sosial (The Legal System: A Social Science Perspective), Nusamedia, Bandung, (2009)

[8] Griffiths J.: What is legal pluralism?. The journal of legal pluralism and unofficial law. 1986 Jan 1;18(24):1-55 (1986)

[9] Irianto S.: Pluralism of women's inheritance law and justice [Indonesian]. Jakarta: Yayasan Pustaka Obor Indonesia, (2016)

[10] Kaelan, Ms.: Filsafat Pancasila Pandangan Hidup Bangsa Indonesia, Paradigma Yogyakarta, (2002).

[11] Kelsen, H.: Teori Umum tentang Hukum dan Negara, 2006, Bandung, Nusamedia \& Nuansa, hlm.161-162; 176-178 (2006) 
[12] Kelsen, H.: Teori Umum tentang Hukum dan Negara, Bandung: Nusamedia \& Nuansa, Bandung, (2006)..

[13] Koentjaraningrat, Bunga Rampai Kebudayaan, Mentalitas dan Pembangunan, Gramedia Pustaka Utama, Jakarta, (1990)

[14] Latif Y.: The complete state Indonesian. Jakarta: Gramedia Pustaka Utama, (2013)

[15] Lauer, R.H. : Perspektif Tentang Perubahan Sosial (Edisi kedua). Rineka Cipta, Jakarta, (1993)

[16] Lincoln YS. Guba EG.: Competing paradigms in qualitative research. In: Denzin NK, Lincoln

[17] Lon YS, Widyawati F. : Cultural Aspects on Child's Development and Parenting in Manggarai, East Nusa Tenggara, Indonesia. Guidena: Jurnal Ilmu Pendidikan, Psikologi, Bimbingan dan Konseling. Jun 30;7(1):130-9 (2017).

[18] Lon, YS, Widyawati, F.: Bride-Wealth: Is There Respect for Women in Manggarai, Eastern Indonesia? Jurnal Humaniora, Vol 30 No 3 (2018).

[19] Lon, Y.S., Widyawati. F,: "Women and Inheritance Rights in Manggarai, Eastern Indonesia: A Fight for Gender Equality." ISLLCE 2019: Proceedings of the First International Seminar on Languare, Literature, Culture and Education, ISLLCE, 15-16 November 2019, Kendari, Indonesia. European Alliance for Innovation, (2020).

[20] Magnis-Suseno, F.: Etika dasar: Masalah-masalah pokok filsafat moral, Kanisius, Yogyakarta, 1987

[21] Mahendra PR, Kurniawan AA. Sistem Pembagian Tanah Ulayat Pada Masyarakat Manggarai Suku Langkas Kelurahan Carep Kecamatan Langke Rembong Kabupaten Manggarai (Tinjauan NilaiNilai Pancasila). Jurnal Pendidikan Kewarganegaraan Undiksha. Feb 29;8(1):106-12. (2020

[22] Mahfud MD.: Sunariyati Hartono, Shidarta, Bernard L.Tanya, Anton F. Susanto, (2013), Dekonstruksi dan Gerakan Pemikiran Hukum Progresif, Yogyakarta: Thafa Media, Yogyakarta (2013).

[23] Martono, N.: (2014), Sosiologi Perubahan Sosial Perspektif Klasik, Modern, Posmodern, dan Poskolonial. Rajawali Pers, Jakarta, (2014).

[24] Menski W.: Flying kites in a global sky: new models of jurisprudence. Socio-Legal Rev..7:1 (2011)

[25] Menski, W.: Comparative Law in a Global Contex: The Legal System of Asia and Afrika (Cambridge University Press, pp.187 ( 2006)

[26] Nggoro,A.M., Sudirman,A.: Discourse Political Law in Indonesia on A Completation of Plato Philosophy, The 2nd Proceeding Indonesia Clean of Corruption in 2020, Jurnal.unissula.ac.id, Faculty of Law, Unissula, Semarang, 20, pp.189-201.(2017).

[27] Nggoro,A.M.: Budaya Manggarai Selayang Pandang, Nusa Indah, Ende, (2006).

[28] Nggoro, AM., FX. Adji Samekto, Sukirno, : Recontextualizing The Patriarchal Dominance Of Manggarai Heritage Customary Law System By Democratic And Gendered Orientation,http://www.ijpronline.com/ViewArticleDetail.aspx?ID=18042,https://doi.org/10.31838/ ijpr/2021.13.01.038, (2021).

[29] Peursen, van, CA.: The strategy of culture. Amsterdam: North-Holland Publishing Company; (1974)

[30] Popper, K. R. J. C. I. : Masyarakat Terbuka dan Musuh-Musuhnya, The Open Society and Its Enemy, diterjemahkan oleh Uzair Fauzan, Pustaka Pelajar, Yogyakarta, (2002)

[31] Rahardjo, S.: Negara Hukum Yang Membahagiakan, Yogyakarta, Publishing, Yogyakarta, (2009)..

[32] Ritter, H.: Dictionary of Concepts in History, Vol.3, Greenwood Publishing Group,(1986).

[33] Samekto,A.: Pergeseran Pemikiran Hukum dari Era Yunani Menuju Postmodernisme, Konpress, Jakarta, (2015).

[34] Samekto,A.: Pergeseran Pemikiran Hukum dari Era Yunani Menuju Postmodernisme, Konpress, Jakarta, (2015)

[35] Soepomo,R.: Bab-Bab Tentang Hukum Adat, Pradnya Paramita,Jakarta, (1987)

[36] Subekti, R.: Kitab Undang-undang Hukum Perdata, Jakarta: Pradnya Paramita, (1985).

[37] Sudarmadi T.: Between colonial legacies and grassroots movements: exploring cultural heritage practice in the Ngaadha and Manngarai Region of Flores. Amsterdam: Faculteit der Letteren, de Vrije Universiteit Amsterdam. (2014)

[38] Sutrisno, M.: dan Hendar Putranto (Editor), Teori-Teori kebudayaan, Kanisius, Yogyakarta,(2013).

[39] Tafsir, A.: Filsafat Umum, Bandung: Remaja Rosdakarya, Bandung (2003). 
[40] Ter Haar,B.: Asas-asas dan Susunan Hukum Adat, Pradnja Paramita, Jakarta, (1960)

[41] Widyawati F.: The Development of Catholicism in Manggarai Eastern Indonesia: Religion, Identity, and Politics, Doctoral dissertation. Gadjah Mada University. (2013) 